ーコミュニケーションー

\title{
無電解プロセスによる酸化銅膜の作製と糖分析への可能性
}

\author{
松原 浩*, 近藤 哲也 ${ }^{\dagger}$, 程内 和範, 山田 明文
}

\section{Fabrication of Copper Oxide Film by Electroless Process and Possibility for Sugar Analysis}

\begin{abstract}
Hiroshi MATSUbARA*, Tetsuya KONDO ${ }^{\dagger}$, Kazunori HodOUCHI and Akifumi YAMADA
\end{abstract}
\author{
Received March 18, 1998 ; Accepted May 19, 1998
}

\section{1 潇}

糖類の高感度で迅速な分析は臨床医学や生化学分野に おいてニーズが增大している”。種くの手法の中でも，亲 の简単な定䉓位下での直接電解酸化法において銅系の電 極はアルカリ中で活性低下を起こしにくく, pmol 程度の 検出が容易である特徽がある ${ }^{2-4)}$.これらは電極としてバ ルク銅 2.31や，銅を電解酸化》したものなどを用いており， 後者は活性が特に長期間持続するとされている.

著者らは無電解めっきと化学的酸化処理を用いた無電 解ブロセスによって酸化銅膜の作製を試みた。本ブロセ スは溶液に浸漬するだけで成膜が可能である特徵を有す るため、これにより粉体などに酸化銅膜を成膜し，電極 としてフローセルへ組み込むといった高度なセル設計が 行える可能性がある、本報では無電解ブロセスによる酸 化銅膜の作製法を示し、クルコースを用いて糖類の流れ 分析に対する適用可能性を調べた。

\section{2 实 卧}

本研究で用いた酸化銅膜作製プロセスを Fig. 1 に示す. 各プロセス間には水洗を行っている。洗浄㧍よびアルカ リ処理を行ったガラス板を塩化すず浴液 $\left(0.26 \mathrm{~mol} \mathrm{dm}^{-3}\right.$ $\left.\mathrm{SnCl}_{2} / 0.12 \mathrm{~mol} \mathrm{dm}{ }^{-3} \mathrm{HCl}\right)$ と塩化パラジウム溶液 $(0.56$ $\mathrm{mmol} \mathrm{dm}{ }^{-3} \mathrm{PdCl}_{2} / 1.2 \mathrm{mmol} \mathrm{dm}^{-3} \mathrm{HCl}$ )を用い触媒化処 理した．触媒化プロセスは 4 回繰り返した。そののち文 献りに示された浴を $\mathrm{pH}=7 ， 60$ Cで用いてニッケル下地膜 を析出, 触媒化処理を 1 回行った後, 文献 ${ }^{6 /} の$ 浴により $60^{\circ}$ Cで 5 分間無電解銅めっきを行い，要塩素酸系溶液に 浸漬して酸化を行って酸化銅膜を得た。サイクリックボ ルタンメトリーにより電気化学特性を調べた。流れ分析

長岡技術科学大学化学系（テ940-2188 長岡市上富岡町 1603-1) Department of Chemistry, Nagaoka University of Technology (1603-1 Kamitomioka, Nagaoka, 940-2188) †現在：(株) 大和化成研究所（广674.0093 明石市二 見町南二見 21-8) Daiwa Fine Chemicals Co., Ltd. (21-8 Minami-Futami, Futami-cho, Akashi, 674-0093)

Key Words : Copper oxide, Electroless process, Glucose analysis, Electrocatalytic oxidation

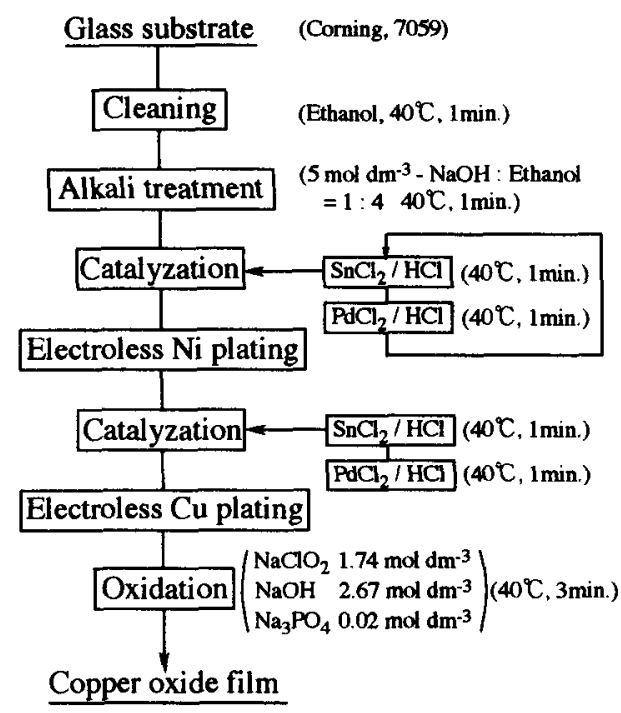

Fig. 1 Fabrication process of the copper oxide film.

(フローインジェクション分析) のフローセル(セル体積 $0.37 \mu \mathrm{l})$ は，Fig.2 に示すものを作製し用いた.

\section{3 结果と考血}

Fig.1 の無電解ブロセスにより得られた茶色の膜には X線回折測定により Cuと $\mathrm{CuO}$ のピークが観察された。 塩酸で酸化膜を溶解除去すると銅めっき膜がみられるこ とから，銅めっき膜の表層が睃化銅 $\mathrm{CuO}$ となり内部は未 酸化のまま残った状態となっていると考えられる。

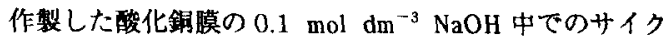
リックボルタモクラムを Fig.3 に示す、図には電極面積 $0.1 \mathrm{~cm}^{2}$ で脱酸素を行わず $1.4 \mathrm{~V}$ より正方向に掃引し数 サイクル後各ピーク高が 10〜15\%程度堿少し定常に達 したものを示した。実線で示したグルコース溶液のボル タモグラム中 +0.6 V 付近に酸化ピークが現れた。この ピーク高はグルコース浱度に依存する．他のピークは銈 


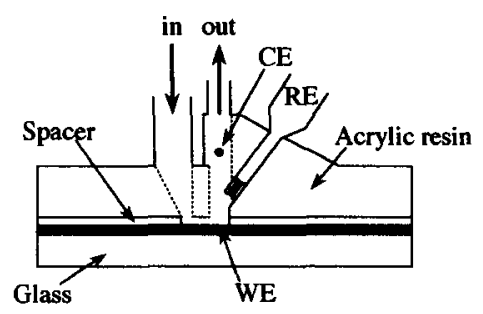

Fig. 2 Structure of the flow cell.

Thickness of spacer : $70 \mu \mathrm{m}$

Area of working electrode : $5.3 \mathrm{~mm}^{2}$

WE : Copper oxide film

RE : SCE

$\mathrm{CE}$ : Platinum wire

の酸化罯元ピークである.これら全てのビークは過去の 報告 2)と同様のものであり，䇘電解ブロセスにより作製し た酸化銅膜もこれらと同様，糖類の検出に対する可能性 が期待される。

以上の酸化銅膜を組み迄んだ Fig.2 のフローセルを用 い, $0.1 \mathrm{M} \mathrm{NaOH}$ をャリヤーとし流速 $1.7 \mathrm{ml} \mathrm{min}^{-1}$, 印 加電位 $+0.62 \mathrm{~V}$ で, 50 川 のグルコース溶液の流れ分析 を試みた．結果を Fig. 4 に示す. $5 \times 10^{-6} \sim 1 \times 10^{-2} \mathrm{~mol}$ $\mathrm{dm}^{-3}$ 程度の広い範囲でグルコース浱度とビーク電流值 が直線関係 $(\mathrm{r}=0.997)$ を示した。 また，検出限界は $2 \mathrm{pmol}$ $(\mathrm{S} / \mathrm{N}=3$, 電流值 $0.1 \mu \mathrm{A})$ であった。 このときのノイズは主 にポンプからの脈流の影響であった。一回の分析所要時 間は 1 分であり，連続打ち込みに対し相対標準偏差 $2 \%$ 程度の良好な再現性が得られた。 また分析終了後, 膜を 3 ケ月間空気中に放置してもほほ同様の特性が得られ,

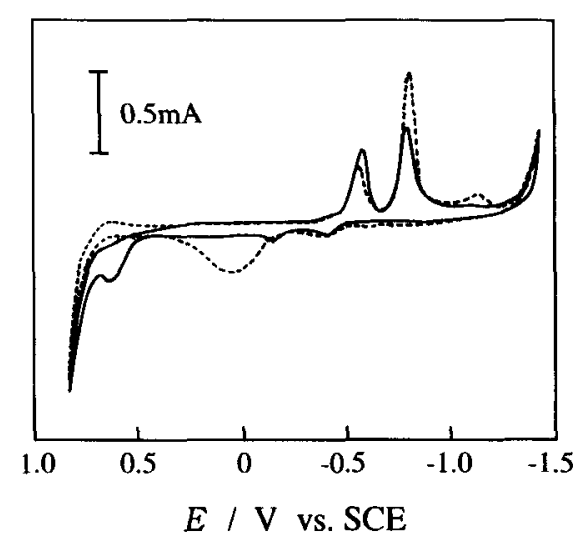

Fig. 3. Cyclic voltammogram of glucose by the copper oxide film.

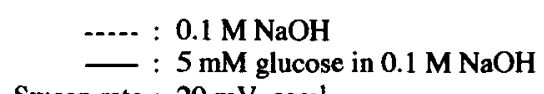

Sweep rate : $20 \mathrm{mV} \mathrm{sec}-1$

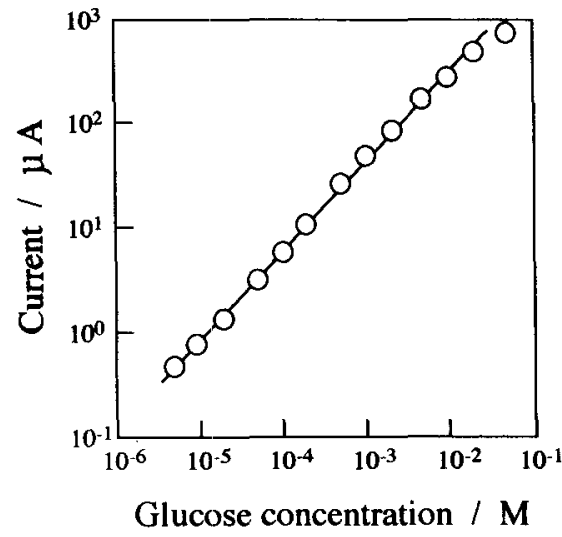

Fig. 4. Calibration curve of glucose by the copper oxide film.

膜は高い安定性を示した。

以上のように無電解ブロセスにより作製した酸化銅膜 はグルコースの流れ分析に適用できる，電流值の直線範 囲や検出限界は，七ル体積や脈流など種々の分析条件で 変化すると考えられるため，これらを最適化することに より，本プロセスの特徽を生かした糖分析のためのフロ ーシステムの設計が可能となるものと期待される。また, 種々の糖類はグルコースとほほ同電位で酸化される 本報では検討を行わなかったが，カラム等により分離を

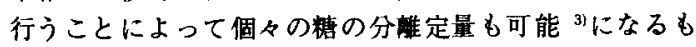
のと考えられる。

\section{4 まとめ}

無電解プロセスで作製した酸化銅膜において $0.1 \mathrm{~mol}$ $\mathrm{dm}^{-3} \mathrm{NaOH}$ 中で $+0.6 \mathrm{~V}$ vs. SCE 付近に現れたグルコー ス浱度に依存する酸化ピークを用い,タルコースの検出 が可能であった。 また膜は空気中で長期間安定であった。

本研究は日本証券奨学財団からの助成をもとに㟟行已 れた。記して媣謝する。

\section{文 th}

1) 大道 櫓, 化学増刊, 117,237(1990).

2) P. Luo, F. Zhang and R. P. Baldwin, Anal. Chim. Acta, 244, 169 (1991).

3) T. Ueda, R. Mitchell, F. Kitamura and A. Nakamoto, J. Chromatogr., 592, 229(1992).

4) K. Kano, M. Torimura, Y. Esaka, M. Goto and T. Ueda, J. Electroanal. Chem., 372, 137(1994).

5) 逢坂哲两，小岩一郎，金属表面技術, 34, 330(1983).

6) 永田弘人, 小岩一郎, 逢坂哲雬, 吉井敏文, 金属表面 技術, 36, 230(1985).

7) 鳥村政基，加納健司，上田輝久，斉藤勝彦，Review of Pol arography, 38, 40 (1992). 